\title{
Applying the hydrodynamic model to optimize the production for crystalline basement reservoir, X field, Cuu Long Basin, Vietnam
}

\author{
Ngoc Thai Ba ${ }^{1}\left(\mathbb{D} \cdot\right.$ Hung Vo Thanh $^{2}\left({ }^{10} \cdot\right.$ Yuichi Sugai $^{2} \cdot$ Kyuro Sasaki $^{2} \cdot$ Ronald Nguele $^{2} \cdot$ Trung Phi Hoang Quang $^{1}$. \\ Minh Luong Bao ${ }^{1} \cdot$ Nam Le Nguyen $\mathrm{Hai}^{2}$
}

Received: 9 June 2019 / Accepted: 17 August 2019 / Published online: 31 August 2019

(C) The Author(s) 2019

\begin{abstract}
Weathered and fractured crystalline basement is known as the important unconventional reservoir in the Cuu Long Basin. Naturally fractured reservoir plays a crucial role in oil exploration to contribute for hydrocarbon production in Vietnam. However, the complexity and heterogeneity of the fractures system in the basement reservoir are challenges for oil and gas production. They require the realistic simulation scenarios to estimate the hydrocarbon potential as well as field development plan of these reservoirs. Thus, this paper aims to propose the feasibility development scenarios to improve oil recovery factor for crystalline basement reservoir, X field, Cuu Long Basin, Vietnam. First, history matching process is validated for the model to fit the actual production data (reservoir pressure, pressure, water cut in each well) in order to approach closer the fluid flow behavior through the reservoir. The manual matching was selected to adjust the actual aquifer size and permeability distribution with limit simulation runs. Next, the highest reliability matching model which approximately reflects the actual fluid flow behavior can be used as the base case to forecast the future reservoir performance through the field development plan. The most potential scenario is to add six new infill production wells, two side track wells and two water injection wells. The forecasted results indicate that this scenario yields $8 \%$ more oil recovery factor compared to the natural drive with thirteen producers. This result suggests that the precise field development plan is to increase the efficiency of the production process by increasing the displacement parameters of residual oil and reservoir sweep efficiency by stimulation. The major contribution of this paper demonstrates the merits of the field development plan in fractured basement reservoir. The findings of this study can help better understand the fluid flow behavior using the production history profiles and field development scenarios of crystalline basement reservoir of Cuu Long Basin.
\end{abstract}

Keywords Crystalline basement $\cdot$ Cuu Long Basin $\cdot$ Field development plan $\cdot$ Production optimization $\cdot$ Vietnam

\section{Introduction}

The average oil recovery around the world is $35 \%$. Improving oil recovery strongly depends on the availability of technology, economical and practical field development plan (Babadagli 2007). Moreover, the chance of exploring the

Ngoc Thai Ba

tbngoc@hcmut.edu.vn

1 Department of Petroleum Geology, Faculty of Geology and Petroleum, Ho Chi Minh City University of Technology, 268 Ly Thuong Kiet, 10 District, Ho Chi Minh City 700000 , Vietnam

2 Department of Earth Resources Engineering, Faculty of Engineering, Kyushu University, 744 Motooka Nishi-ku, Fukuoka 819-0395, Japan conventional reservoir in giant fields remarkably decreased (Blaskovich 2000). Therefore, the exploration and production hydrocarbon field turned into unconventional reservoirs. Recently, the oil and gas industry in Vietnam has focused on the fractured basement reservoir. This reservoir contributes up to $90 \%$ of oil production compared with conventional reservoir (Giao et al. 2011). Recently, many studies determined many aspects of unconventional reservoirs using experimental and numerical simulation (He et al. 2019; Qiu et al. 2019; Tan et al. 2019). Tan et al. (2019) proposed the new and simple method of measurement to investigate the criticality of fluids confined in nanopores. Also, Qiu et al. (2019) introduced a useful technique to investigate the phase transition of pure fluids and mixtures in nanopores. In the numerical simulation for shale gas, He et al. (2019) applied 
the theoretical approach of material balance to determine the original gas-in-place of shale gas reservoir.

Generally, the characteristic of basement reservoir is that it could not perform like sandstone reservoir. The current issue is to design effective reservoir management through field development strategy. There are several studies conducted for basement reservoirs such as the matrix and fracture characterization (Dakhelpour-Ghoveifel et al. 2018; Saboorian-Jooybari et al. 2015, 2016), well test analysis (Dejam et al. 2018; Mashayekhizadeh et al. 2011; Zhang et al. 2018) and overview of geological and production characteristic (Gutmanis 2009). Moreover, the history matching process is one of the challenges for unconventional and basement reservoirs (Azim 2016; Dachanuwattana et al. 2019; Dang et al. 2011; Jeong et al. 2013; León Carrera et al. 2018; Nguyen et al. 2011). These authors proposed an efficient workflow to handle the difficulty of modeling and history matching in fractured basement reservoirs. However, a field development plan is one of the crucial tasks that can enhance reservoir performance and maximize economic value that has not yet been mentioned in the case of basement reservoir. In recent years, many studies have focused on numerical simulation for improving oil recovery in unconventional reservoirs (Alfarge et al. 2018; Izadmehr et al. 2018). Alfarge et al. (2018) introduced the way to select the best type of miscible gases to enhance oil recovery in shale oil reservoirs. Furthermore, Izadmehr et al. (2018) considered the injector rate, number and installation of submersible pumps to rank the development scenarios for the oil field.

For crystalline basement reservoir, the bottom hole pressure needs to maintain through natural drive mechanism in the reservoir. It is called the primary stage in production oil field's life cycle. This stage is not efficient if the reservoir manager has not proposed an effective plan. Conventionally, reservoir engineers advise on the field development plan through sensitivity simulation studies (Khan and Awotunde 2018). Recently, many researchers have given much attention to field development plans for production optimization (Ashraf et al. 2019; Isebor and Durlofsky 2014; Santos et al. 2017; Wilson and Durlofsky 2013; Yang et al. 2017). Ashraf et al. (2019) in integrated well log and 3D seismic attributes to evaluate the potential development area. This study predicted the spatial distribution of sweet spots of the heterogeneous reservoir in Sawan gas field, Pakistan. Also, Yang et al. (2017) also presented a hybrid algorithm for field development in a mature oil field. This work stated that well conversion schedules are essential for economic field development scenarios. Also, Isebor and Durlofsky (2014) employed particle swarm optimization-mesh adaptive direct search to maximize expected reservoir performance considering the risk associated with the worst-case scenario. Another study was proposed by Santos et al. (2017) for optimal production strategy significantly to increase the expected value of objective function while reducing the downside risk. Moreover, Wilson and Durlofsky (2013) adapted the surrogate modeling procedure to optimize the field development scenarios considering net present values in Barnett Shale.

However, production optimization through field development has not been proposed in crystalline basement reservoir. Therefore, this paper considered the crystalline basement reservoir in X Field, offshore Vietnam for field development design through optimization of oil production.

First, materials and methods are presented. The history matching process is conducted to validate the reservoir model using water cut, bottom hole pressure and tubing head pressure of each well. The history matched model used for the field development strategy through multiple simulation scenarios, precisely well spacing, water injection, infill drilling, artificial lift design. The selection of the most potential scenario is based on improving oil recovery and economic aspects for a future development plan in crystalline basement reservoir. Figure 1 depicts the sketch of this workflow.

The main difference between this work and previous studies is the simple and efficient procedure for history matching and field development plan for crystalline basement reservoir. The manual history matching process could be achieved after several simulation runs by changing aquifer size and permeability distribution. Moreover, the field development plan considered the natural drive mechanism and an artificial system option to enhance well performance. They result in higher economic value of the future development plan as well as the risk mitigation for production operation in real field. Due to flexibility and efficiency of this work, it could be easily applied in other basement reservoirs in Cuu Long Basin or other basin.

To the best of our knowledge, the presented process of this field development plan had never been conducted in the literature, especially in crystalline basement reservoir.

\section{Geological background}

The $\mathrm{X}$ field is located on the boundaries of the two licensed blocks (09-1 and 09-3) on the south of Vietnam continental shelf, $135 \mathrm{~km}$ from the Vung Tau Port and $110 \mathrm{~km}$ from the nearest coastline. Vung Tau city is connected with Ho Chi Minh city by a highway (distance $125 \mathrm{~km}$ ), as well as by a waterway that is accessible to practically all the types of vessels (distance $80 \mathrm{~km}$ ).

The general location map is shown in Fig. 1. Exploration drilling in the area was carried out with jack-up rigs. The power supply sources for drilling are internal combustion engines. Sea depth in the area is $25-50 \mathrm{~m}$. Water temperature varies in a year from 250 to $320^{\circ} \mathrm{C}$. The water salinity is $27-35 \mathrm{~g} / 1$. 


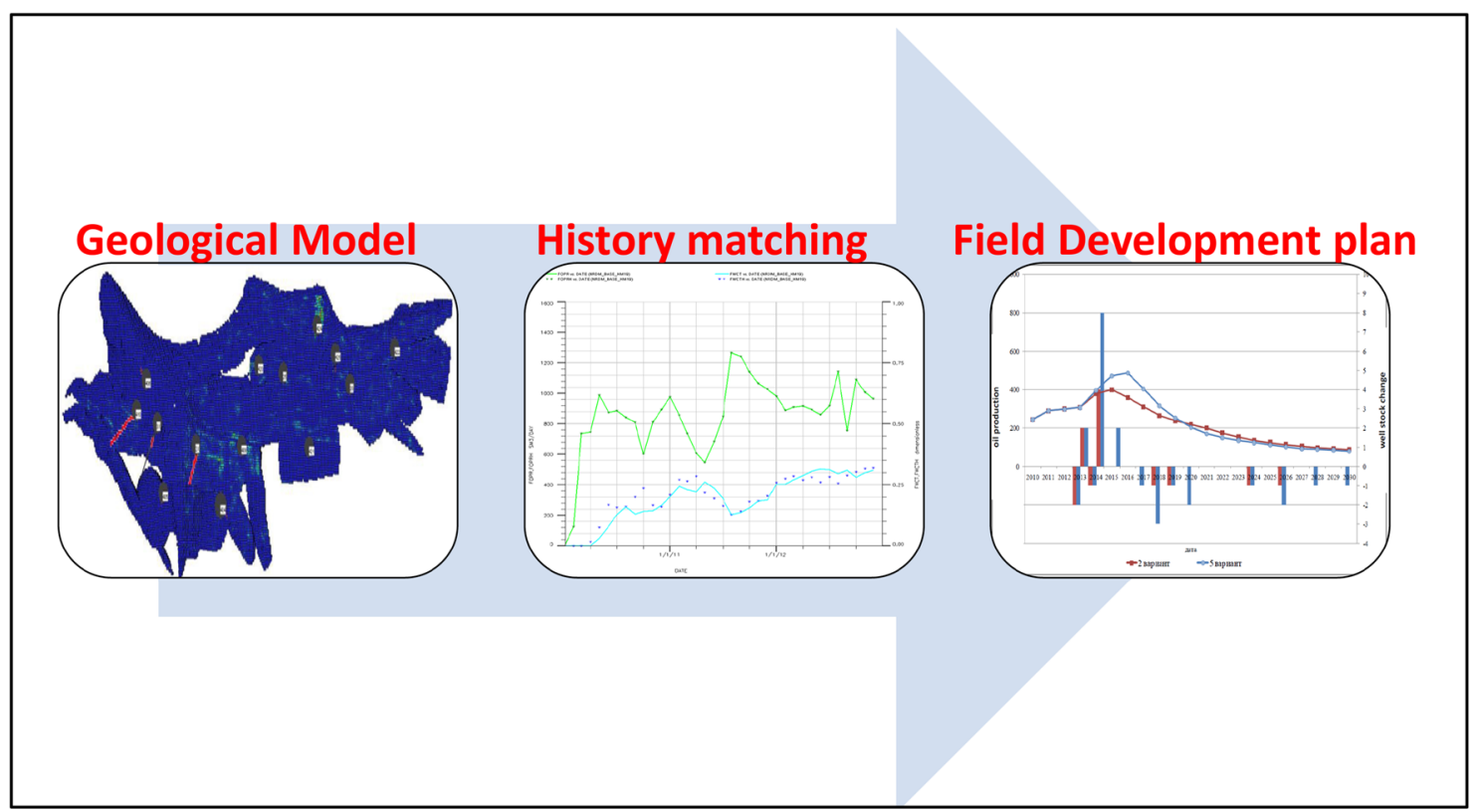

Fig. 1 The general sketch of this study

In tectonic terms, the above-mentioned tectonic element is a central horst, which formation is closely related to rifting and the development was activated since the early Cenozoic period and determined by the presence of the three different structural columns: basement (Mesozoic), intermediate (Paleocene) and sub-platform (Miocene-Quaternary) in the section.
The general stratigraphy of $\mathrm{X}$ field is following:

The $\mathrm{X}$ geological section is represented by crystalline basement rock and Paleogene (Oligocene), Neogene (Miocene, Pliocene) and Quaternary sediments (Fig. 2).

According to geophysical data, thickness of sedimentary cover in area varies from 3.3 to $3.8 \mathrm{~km}$ at the top of the
Fig. 2 Location of studied area in Cuu Long Basin

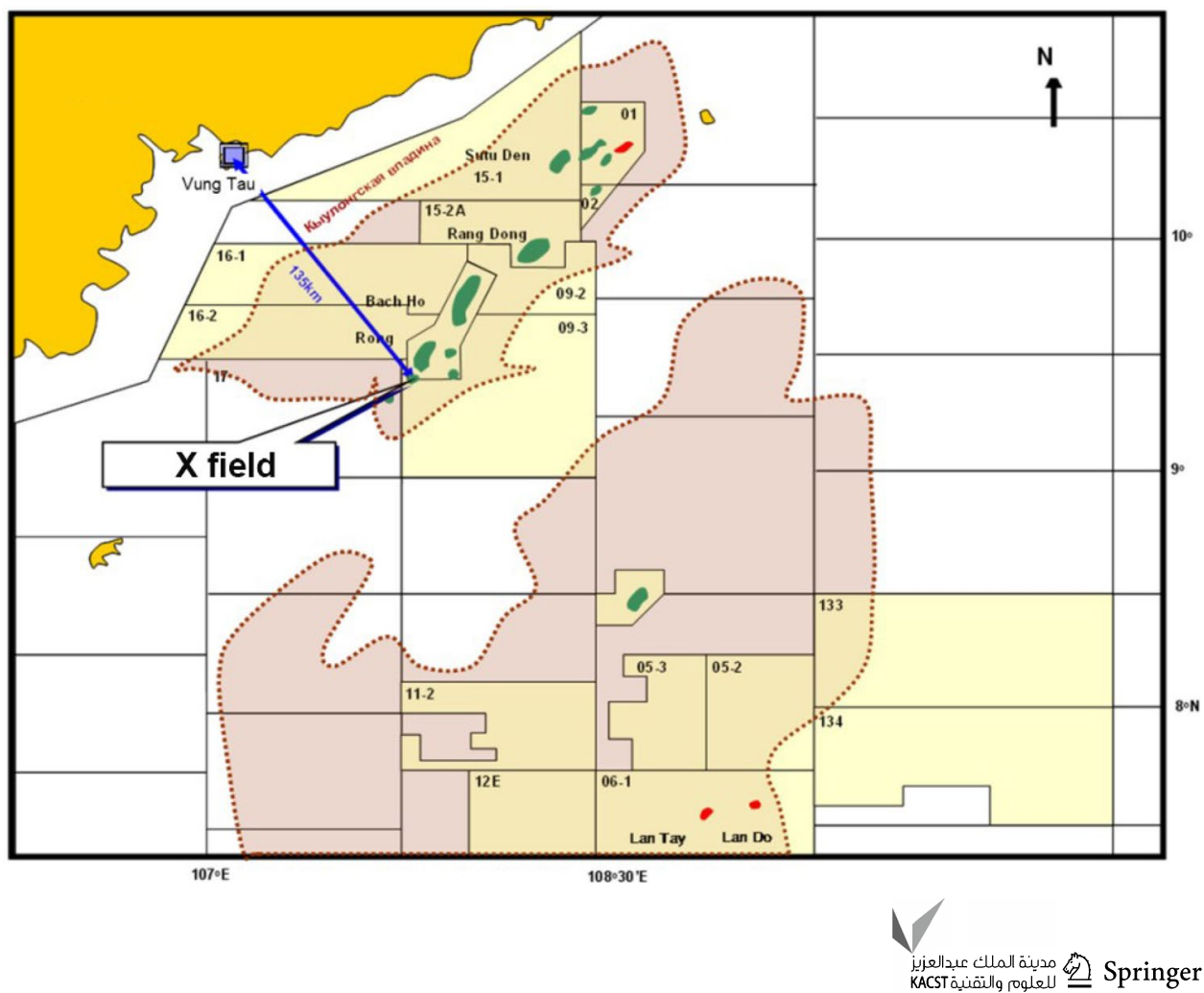


most uplifted structures (by well data) to $5.0 \mathrm{~km}$ at the most subsided parts of grabens (by seismic data).

According to the core materials, the basement within the block is represented by biotite gneisses, gneissoid granites and hornblende diorites of bright gray, subjected to weathering and metamorphism in different levels.

The open void of gneisses was studied only in eight colored slices. Average value of the open cavitation is about $1.58 \%$ at variation of $0.8-2.8 \%$. It was practically solely formed by fractures $(1.53 \%)$, and the porosity is negligibly small - 0/04\%.

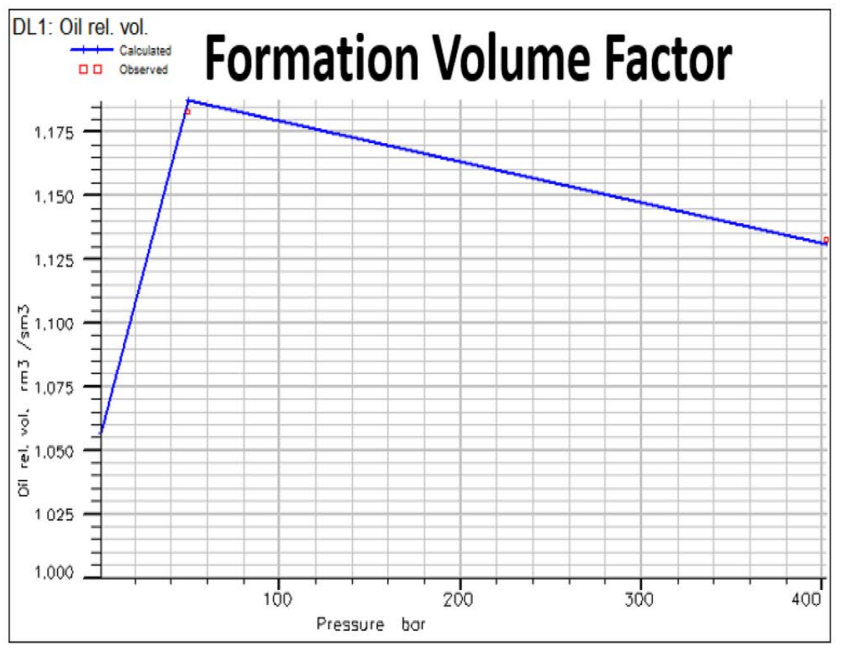

\section{Materials and method}

The OIIP of $\mathrm{X}$ Field for $2 \mathrm{P}$ reserves is $34.172 \mathrm{MM} \mathrm{SM}^{3}$. Until the end of November 2012, the cumulative oil produced from this reservoir reached $930994 \mathrm{SM}^{3}$, and cumulative water is $257,421 \mathrm{SM}^{3}$. Currently, there are a total of 14 wells with 13 wells producing oil. The field has been producing oil from January 2010.

During exploration phase, four samples were taken: 20, $25,2 \mathrm{X}$ and $3 \mathrm{X}$. The carefully analyzed laboratory data were used to match PVT models applying PVTi modules. The PVT data taken from well 25 were selected for simulation model. Figure 3 depicts a summary of matching results of key PVT parameters such as formation volume factor, oil viscosity and liquid density.
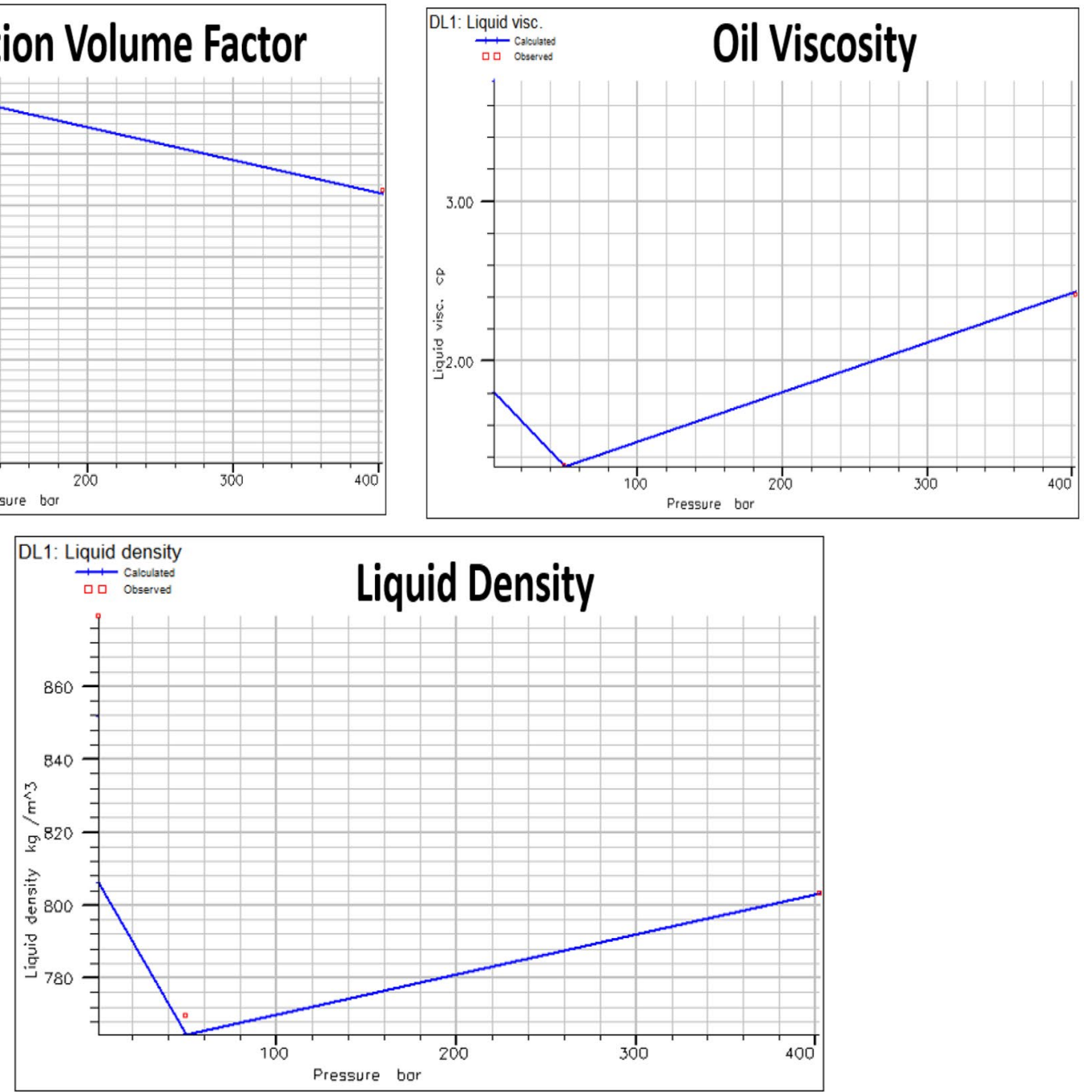

Fig. 3 Summary of matching result of key PVT parameters 
Table 1 Oil characteristics from well R25

\begin{tabular}{ll}
\hline Oil type & Black oil \\
\hline Bubble point, $\mathrm{Pb}$ & $49.5 \mathrm{bar}$ \\
Oil density at $\mathrm{Pb}$ & $796.8 \mathrm{~g} / \mathrm{cc}$ \\
Oil viscosity at $\mathrm{Pb}$ & $1.35 \mathrm{cp}$ \\
Oil formation volume factor at $\mathrm{Pb}$ & $1.183\left(\mathrm{~m}^{3} / \mathrm{SM}^{3}\right)$ \\
Initial oil formation volume factor, Boi & $1.133\left(\mathrm{~m}^{3} / \mathrm{SM}^{3}\right)$ \\
Solution gas & $25.16\left(\mathrm{~m}^{3} / \mathrm{m}^{3}\right)$ \\
\hline
\end{tabular}

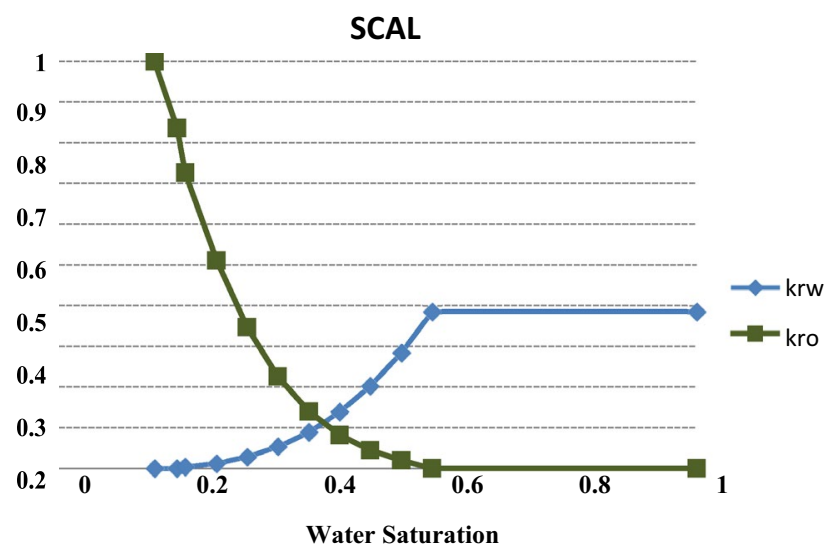

Fig. 4 Water-oil relative permeability curve

\section{Oil properties}

The main characteristics of the basement reservoir fluid from well R25 are shown in Table 1.

\section{Rock properties}

The water-oil relative permeability and gas-oil relative permeability curves using in $\mathrm{X}$ basement reservoir simulation were approximately replicated (analog method) from Bach Ho field. The final data of relative permeability is shown in Fig. 4.

The reservoir simulation in this study was done using ECLIPSE Black Oil Simulator. History matching was conducted in order to validate with the actual production data. The best history matching models were used to predict further development scenarios and improve oil recovery (IOR) planning in crystalline fractured basement reservoir. Several options from field development will be performed to determine the suitable strategy for reservoir management. Comparing case by case through reservoir simulation provides the optimal plan to maximize the oil recovery.

Field development plan considered the primary to the secondary stage of the reservoir. Therefore, the proposed field development design in this work would provide the efficient procedure to optimize production in crystalline basement reservoir.

The details of options for field development are as following:

- Option 1 (base case): considering the non-interruption of the field development in the current conditions and in the existing regime

- Option 2: considering the addition to the base case by adding four producers and two sidetracks and converting two wells into injectors.

- Option 3: considering the addition to the base case by adding six producers and two sidetracks and converting two wells into injectors.

- Option 4: considering the addition to the base case by adding eight producers and two sidetracks and converting two wells into injectors.

- Option 5: considering the addition to the base case by adding ten producers and two sidetracks and converting two wells into injectors.

To perform these options, related to the impact of the linear (buffer) pressure, bottom hole pressure, the commencement date of water injection, the required level of voidage ratio, selection of candidate wells convert into injector and their number, additional intermediate calculations had been conducted:

- Bottom hole pressure: 100 at/tubing head pressure: 16 at

- Selection of number of wells and candidates: 2 or 3 injection wells

- The candidates of transfer underwater injection: 405, 406, 420, 422

- The level of voidage ratio: $60 \% / 70 \% / 80 \% / 90 \% / 100 \%$;

- The beginning of water injection: 2014/2015/2016/2017.

The location of each new well and its profile can be updated with the new geological field data obtained after accomplishing previous development and current status of the field development.

\section{Hydrodynamic model}

The model dimension is $338 \times 120 \times 27(X \times Y \times Z)$. It is modeled by $1,095,120$ cells, including 213943 active cells. The dimension of cells is $30 \mathrm{~m} \times 30 \mathrm{~m} \times 30 \mathrm{~m}(\mathrm{DX} \times \mathrm{DY} \times \mathrm{DZ})$. In addition, the initial field reservoir pressure was determined from pressure survey data at $400 \mathrm{~atm}$ at depth of $3950 \mathrm{~m}$ TVDss. The initial temperature was ranged from 120 to $137^{\circ} \mathrm{C}$. 
Fig. 5 Distribution of porosity and permeability model
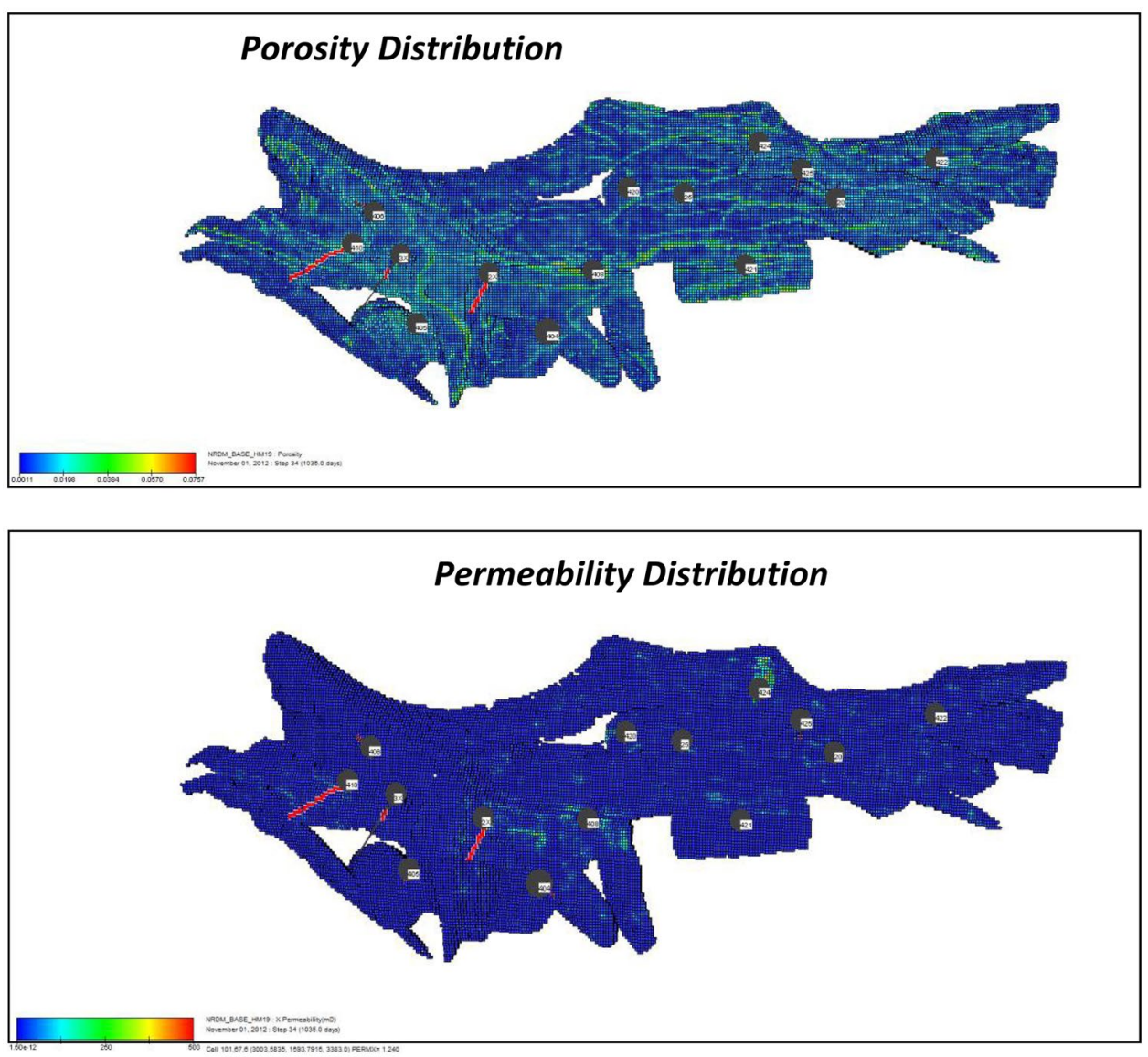

Table 2 Comparison between OIIP defined by volumetric method and dynamic model

\begin{tabular}{lll}
\hline Volumetric calculation & Dynamic calculation & Difference \\
\hline OIIP $\left(\mathrm{MMSM}^{3}\right)$ & OIIP $\left(\mathrm{MMSM}^{3}\right)$ & $\%$ \\
34.172 & 33.49 & 1.9 \\
\hline
\end{tabular}

Moreover, the reservoir is highly heterogeneous with fracture distribution in geological models. The reservoir models are up-scaled directly from high-resolution static model. Figure 5 highlights the distribution of porosity and permeability in crystalline fractured basement reservoir.

In order to quality control the difference between static and dynamic model, the comparison between initial oil in place in the simulation model by using the approved number of oil in place determined by volumetric method shows in Table 2. The difference between volumetric calculation and dynamic calculation is only $1.9 \%$. This result indicated that the dynamic calculation could be used for further evaluation.

\section{Results and discussion}

\section{History matching}

Before individual wells are matched, we ensured firstly that the field matching is up to the satisfaction. This is to ensure the validity of our history matching procedure. It is to be reminded that not all the wells are calibrated to achieve the history matching; we are focusing only on some key wells which mainly contribute to field oil production. After initialization is completed and validated, we proceed to the history matching phase. Since there are a lot of uncertainties with this model, critical parameters were identified and sensitized to check the overall effect toward the performance of the field as well as among the producing well.

In this study, the sensitivity variables being matched for the simulation are aquifer support and permeability distribution.

In order to obtain the good match, some modifications on aquifer support and permeability were applied; gas lift volume and VFP tables were also specified to match the tubing head pressure. History matching results for field water cut and WBHP, WTHP, WWCT and WBP9 and also by 


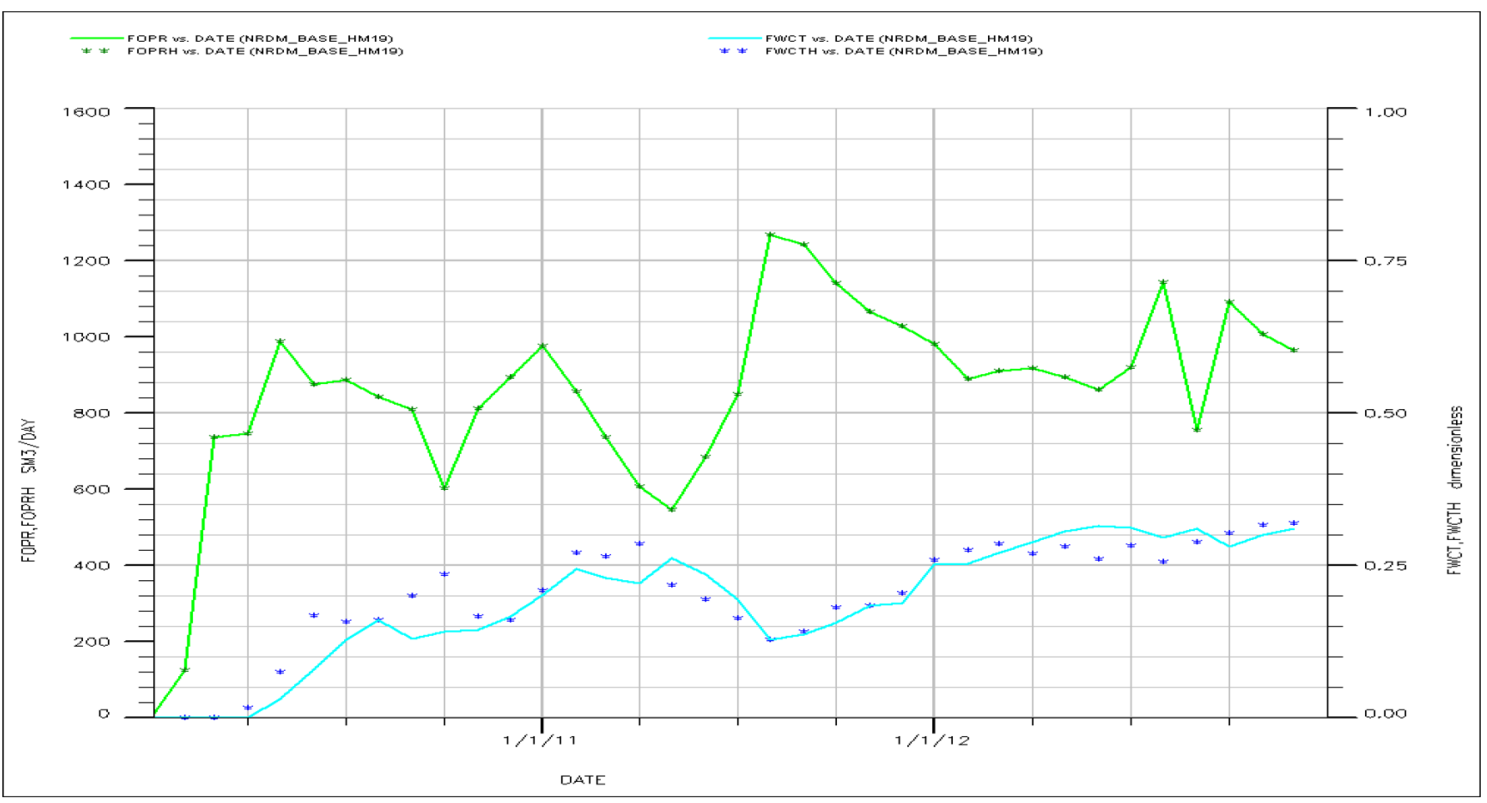

Fig. 6 Field matching results

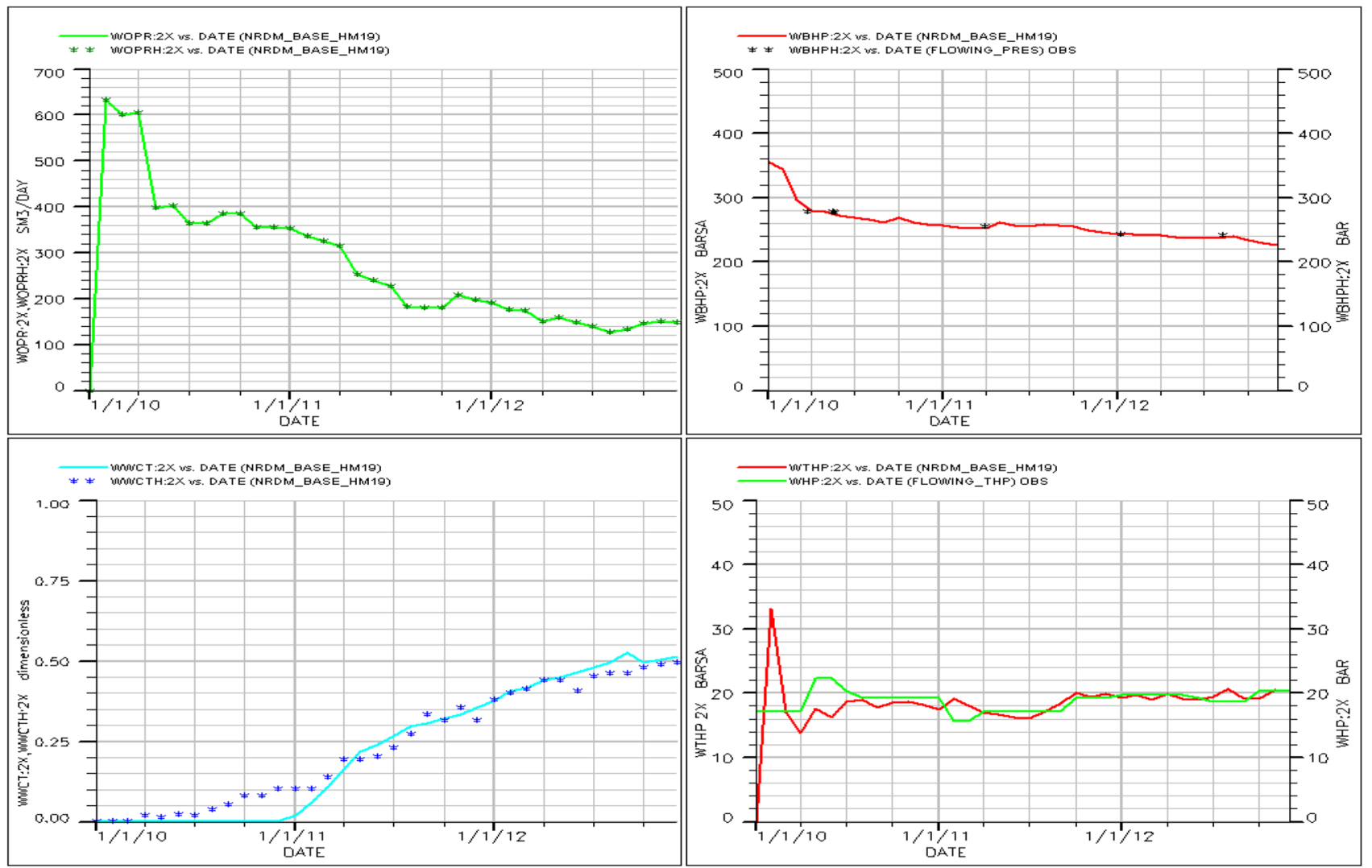

Fig. 7 Matching results of well 


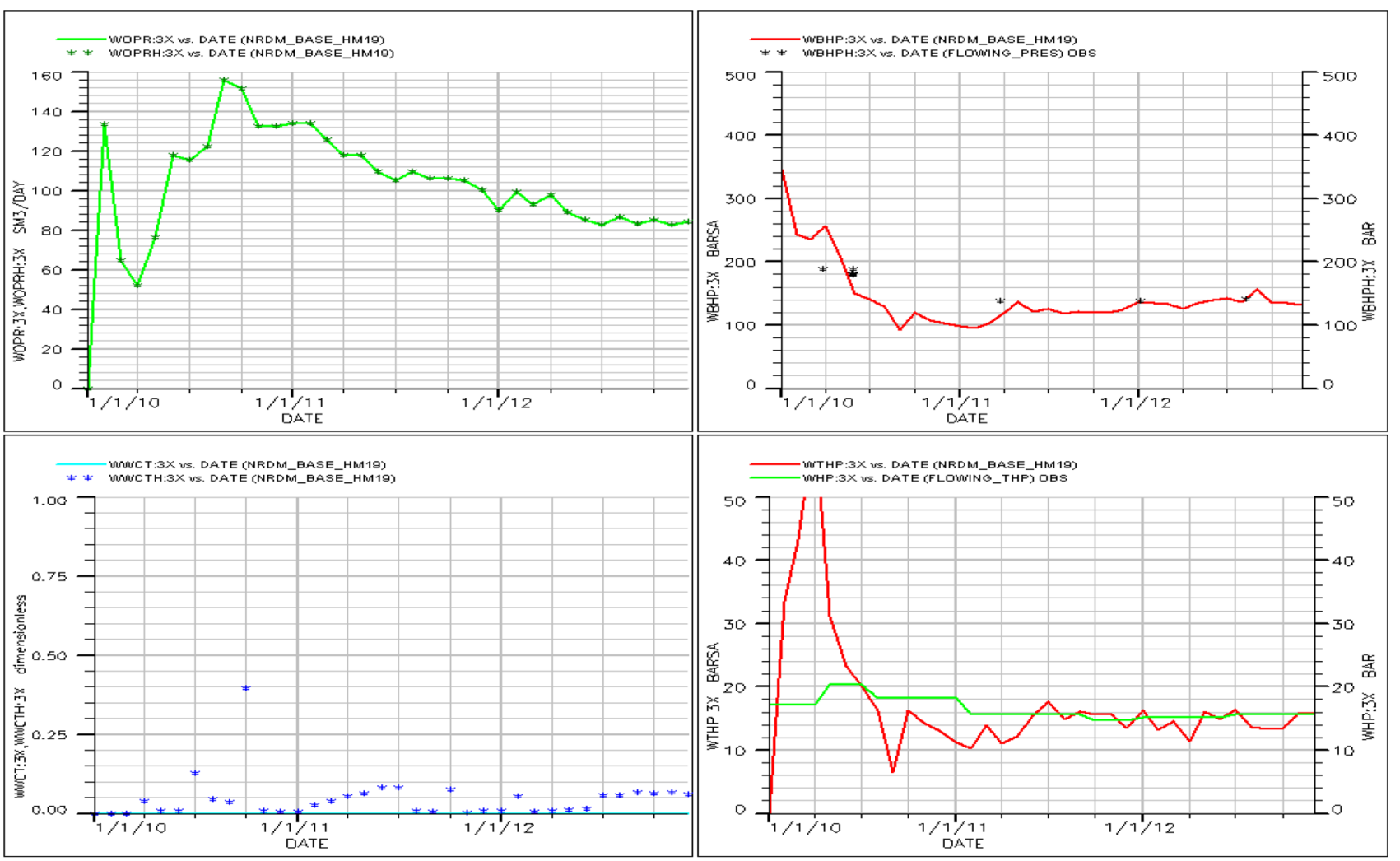

Fig. 8 Matching results of well 3X
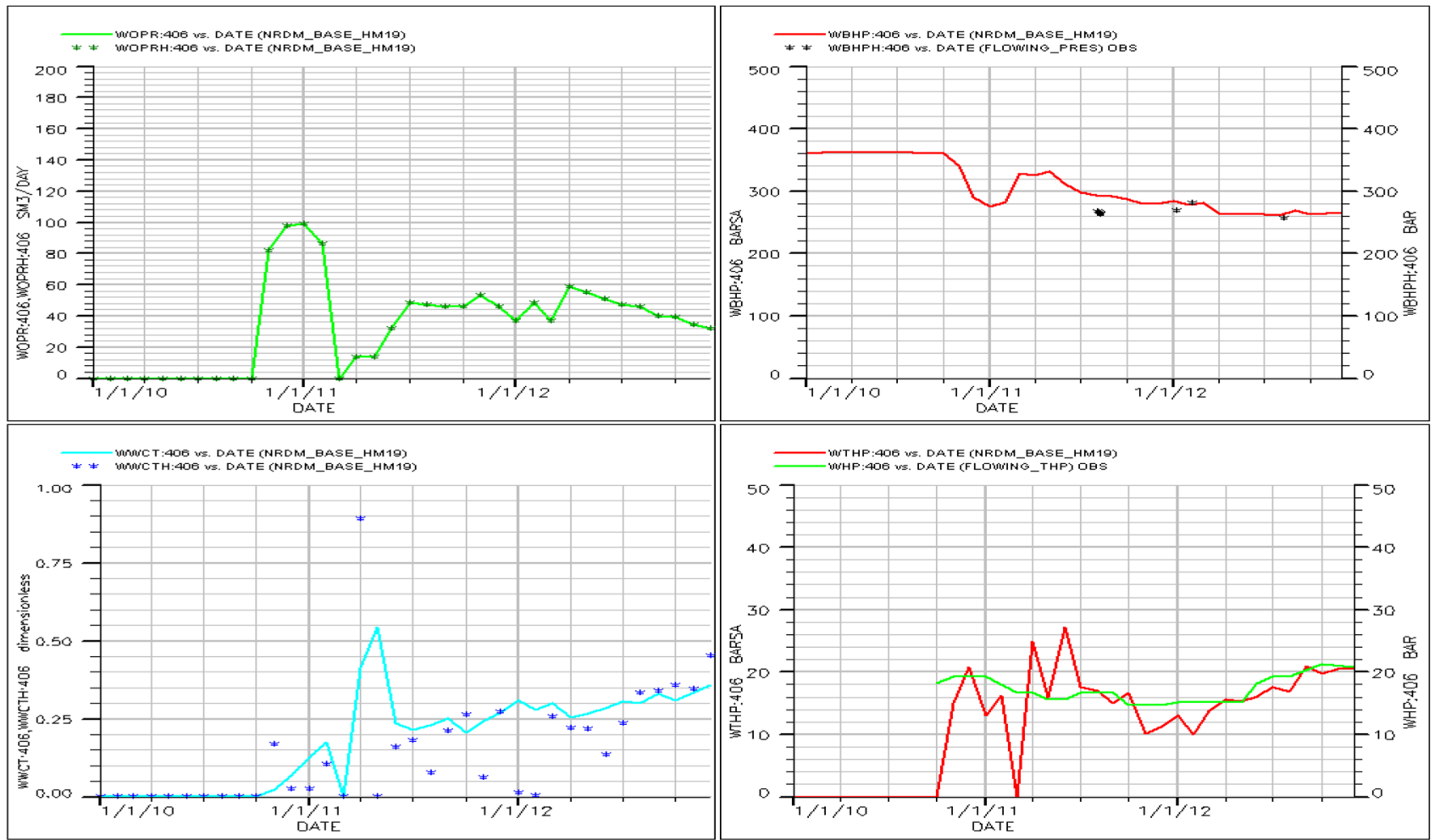

Fig. 9 Matching results of well 406 


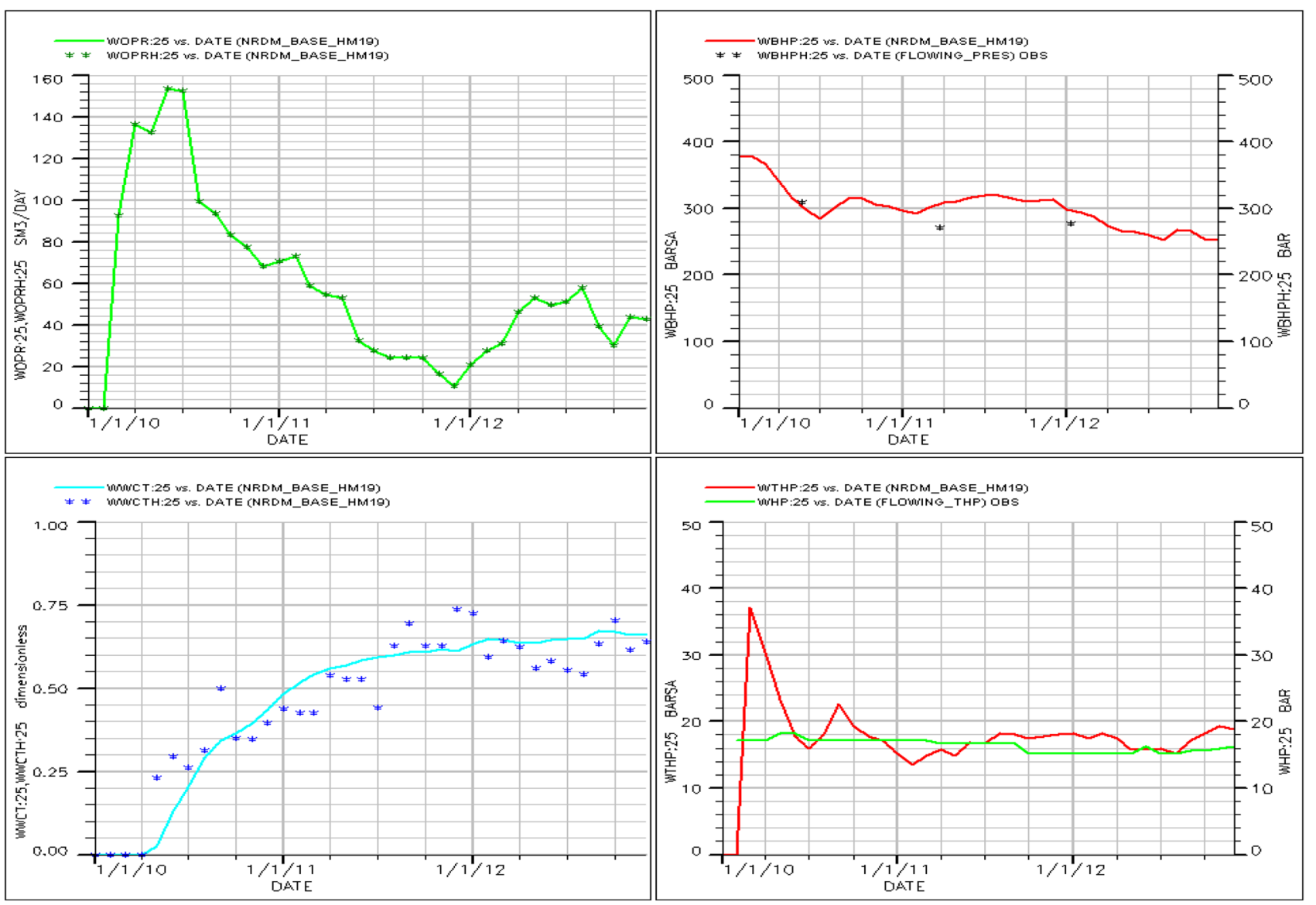

Fig. 10 Matching results of well 25

individual wells ( $85 \%$ of wells) showed a good match and are presented in Figs. 6, 7, 8, 9, 10 and 11.

It was unnecessary to apply an optimization tool for assisted history matching because the matching in this work was conducted through the small number of runs after adjusting aquifer size and permeability distribution. The mismatch between simulated and observed results in Figs. 5, 6, 7, 8, 9 and 10 to emphasize the effects of history matching process while calibrating the aquifer size and permeability model.

Figure 12 depicts the cross-validation of cumulative oil and liquid production. The nearly perfect matching between calculated and observed data is good indicator to reflect reservoir fluid flow behavior in crystalline basement reservoir. Thus, the validated reservoir model could be used to predict future reservoir performance and field development plan.

\section{Field development plan}

The average daily maximum injectivity of injection wells is assumed to be $600 \mathrm{~m}^{3} /$ day according to the data of pilot injection. It is considered for conversion when the oil flow rate is $2 \mathrm{t} / \mathrm{d}$ or maximum water cut is $98 \%$. The proposed options on the hydrodynamic model showed the following:

Option 1 (base case) considers the non-interruption of the field development of the oil reservoir by the natural energy. Reservoir development is characterized by sublinear reduction of oil rates associated with the reservoir pressure drop and increasing water cut.

Option 2 (base case +4 new wells +2 sidetracks +2 injection wells) considers the increase in the well number (drilling wells 407, 409, 423, 426), sidetracking from wells 404 and 421 and the organization of the reservoir pressure maintenance system (wells 406, 420)

Option 3 (base case +6 new wells +2 sidetracks +2 injection wells) considers the same measures as the option 2, but with further increase in the well number by 2 (drilling wells 411 and 427). This scenario is most similar to the scenario 3, which was recommended for applying in the EPP 2007. The well number is 20 wells, including 18 production wells and 2 injection wells. On each WHP 2 reserve slots will remain. 


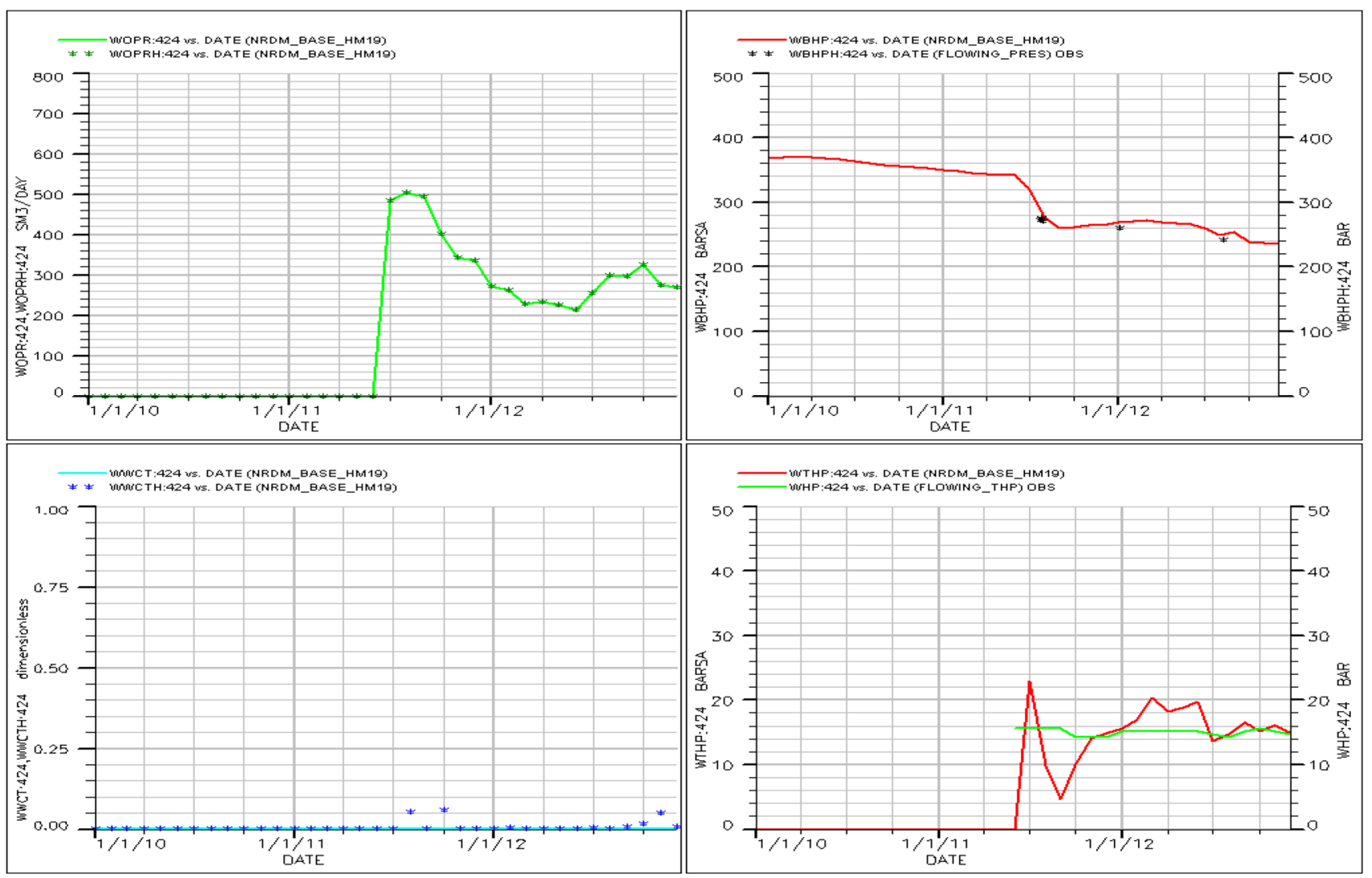

Fig. 11 Matching results of well 424

Option 4 (base case +8 new wells +2 sidetracks +2 injection wells) in contrast to the previous option, it considers the addition of two wells.

Option 5 (base case +10 new wells +2 sidetracks +2 injection wells) considers the maximum use of the opportunities of adding wells from WHP.

The predictive technological parameters are presented in Fig. 13. The main technological parameters of the considered options are shown in Table 3, which implies the full-rated level oil recovery reserves is achieved in case of applying the option 5 .

Simulation results indicated the increase in the well number is well correlated with cumulative oil production rate 1 and is according to the value of the oil recovery factor, but in recalculating the recoverable oil for one well, the effect is ambiguous.

This somewhat reduces the attractiveness of this scenario. Specific volume of oil production rate in the option 2 is superior to others. This indicates the technological effectiveness of this option. Comparison of specific production rate in areas showed high effectiveness in the down spacing on RC-DM relative to RC-4 (Table 4).

The advantage of the option 5, first of all, is in ensuring the high levels of oil recovery in the coming years (5-6 years) after the beginning of works. The primary and main disadvantage is the high rate of well conversion in a short period of time (minus 7 units during the period from 2017 to 2020) and a slight increase in the recoverable oil reserves. The advantage of the option 2 is in the fullest use of the drilled well number, the optimum process of well conversion, stable dynamics of the drop of recovery rates and least costs (Fig. 14). This option is the base case for the next three options, which propose the development of one of the main statuses of the process flow diagram-drilling of new wells. Therefore, in the conditions of high geological field and economic uncertainty, the option 2 is more preferred. On the basis of the situation that will develop in the future, further development on the proposed scenarios is possible. This will allow to take a more justified decision on the down spacing. One of the possible options of the down spacing is to increase the number of sidetracks that economically costs 

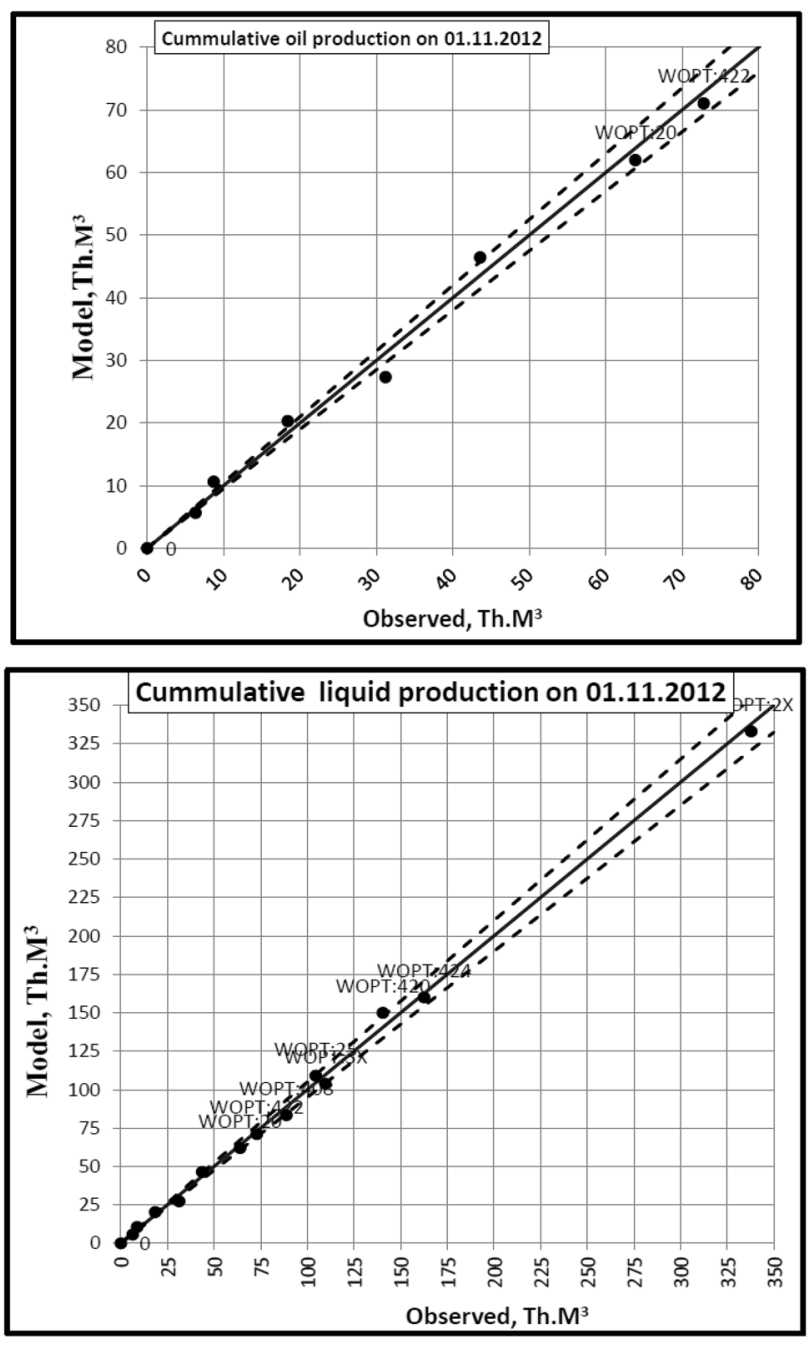

Fig. 12 Cross-plot of cumulative oil and liquid production

less than drilling a new well. Start of the well conversion is predicted in the years 2018-2019.

Comparison of the option 2 with options 3 and 4 confirms the above- mentioned observation. It should give an explanation on close enough parameters of the cumulative production rate of the options 2 and 3. At the end of the forecast period, the difference between them is only six thousand tons. This is explained as follows: the putting of new wells into production is reflected by the increase in production rate in the initial period, but later, as a result of more intense flooding, there is a reduction in oil production rates. In the end, the effect of drilling of two additional wells in the period from 2014 to 2020 is leveled by negative (according to comparison with the option 2) dynamics of the yearly recovery rates after 2021 . The similar analysis of the predictive production showed signs of interference, when the operation of the new wells affected the production regime of the previously drilled wells in the reservoir.

There is a value and sequence of putting wells into production, as in the option 2, two pairs of wells (407, 423 and $409,426)$ are put into production with high predictive levels of the cumulative oil (1694 and 388 thousand tons, respectively). The option 3 proposed to place two wells into production $(411,427)$ with less cumulative indicators $(335,000$ tones). Moreover, in the option 4, two new wells (P1, P2) will produce 623,000 tons, while in the option 5 including the wells $\mathrm{P} 3$ and $\mathrm{P} 4$ has cumulative production rate of 323,000 tones. Thus, by changing the sequence of placing wells into production, it is possible to receive a big difference between the options, but in the level of total reserve recovery, it is reflected weakly.

It noted the complexity of the forecasting of the flooding process the conditions of fractured reservoirs of the basement reservoirs of the complicated faults. The simulation result shows that under the conditions of satisfactory adaptation of the hydrodynamic model, a sufficiently stable forecast for the next 3-5 years for oil production is ensured, but the reliability of the estimated flooding remains low due to intricately replicable process of the water movement in these geological conditions. The driving curve of $\mathrm{X}$ field has a good shape compared to adjacent structures (Fig. 15). After starting of the flooding process due to water breakthrough at an early stage of development, the probability of the earlier flooding of new wells is higher than the probability which was obtained on the filtration model (an average of 3 years), i.e., there is a possibility of failure to achieve predicted maximum annual recovery rates in the volumes that have been calculated previously.

Therefore, to determine the effect on the values of the oil recovery factor of the well number and the production regime, preliminary calculations (12 scenarios, Table 5) are shown.

Comparison and analysis of the results showed the following:

- Increase in the well number is reflected by enhancement of the oil recovery factor (ORF) from 0.014 to 0.023 ;

- Application of the reservoir pressure maintenance system leads to an increase in the ORF from 0.07 to 0.078 .

After preliminary calculations, it was determined five major development options, which consider the drilling of new wells and the creation of an artificial reservoir pressure maintenance system. The greatest value of ORF is achieved in the option 5 and is equal to 0.163 , which is more than 0.08 for the one obtained in the base case. 

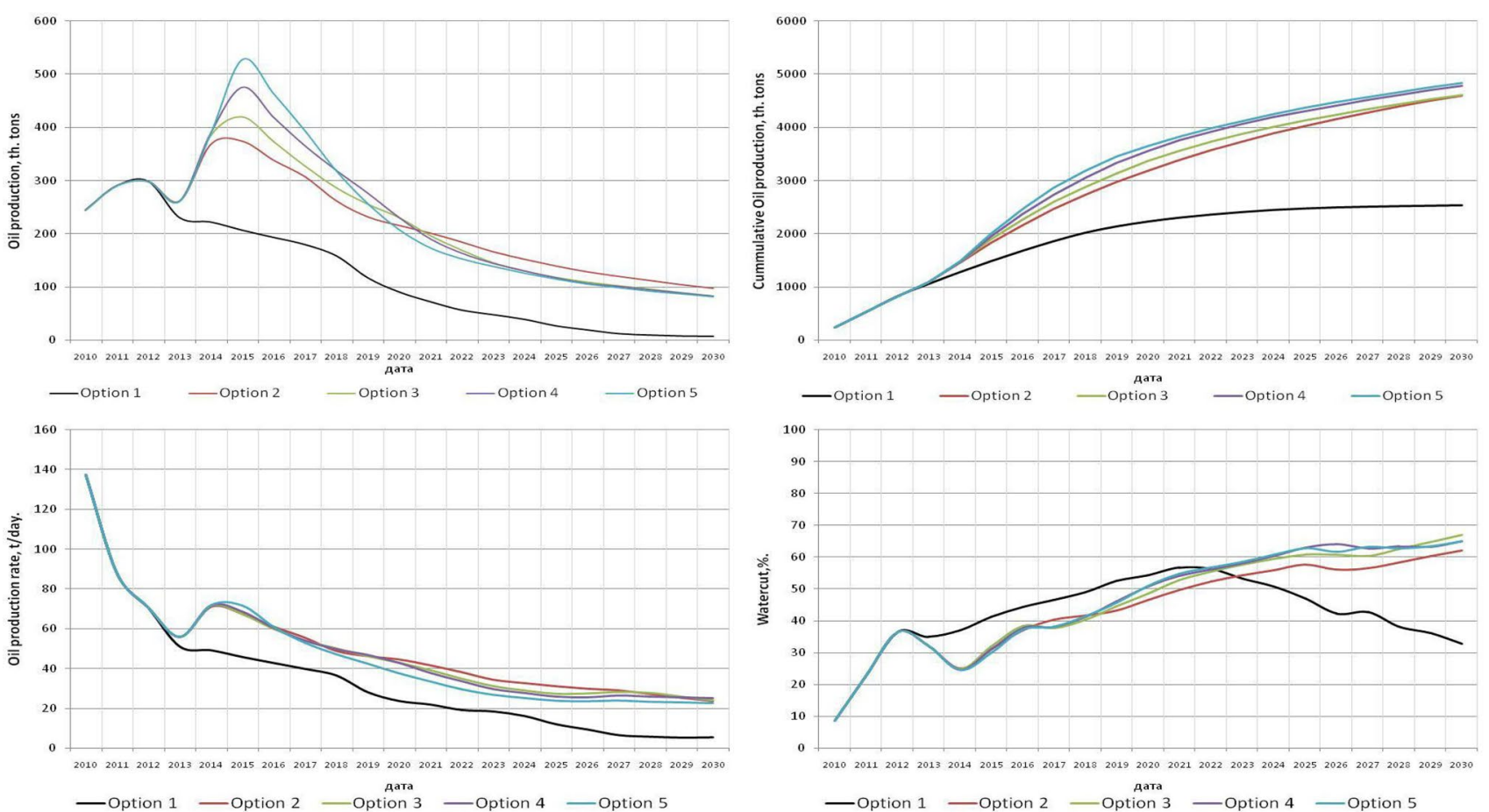

Fig. 13 Predictive technological parameters of development options

Table 3 Summary of technological parameters of the calculated options

\begin{tabular}{|c|c|c|c|c|c|c|}
\hline Nos. & Parameters & Option 1 & Option 2 & Option 3 & Option 4 & Option 5 \\
\hline 1. & Development system, type of impact & Natural drive & \multicolumn{4}{|c|}{$\begin{array}{l}\text { Water injection for reservoir pressure mainte- } \\
\text { nance in the bottom part of the reservoir }\end{array}$} \\
\hline 2. & Well spacing, $10^{-4} \mathrm{~m}^{2}$ & 138 & 97 & 88 & 81 & 74 \\
\hline \multirow[t]{4}{*}{3.} & Design production level of: & & & & & \\
\hline & Oil, thousand tons & 230 & 374 & 419 & 476 & 529 \\
\hline & Fluid, thousand tons & 354 & 542 & 617 & 689 & 753 \\
\hline & Water injection, thousand $\mathrm{m}^{3}$ & - & 301 & 298 & 311 & 311 \\
\hline 4. & Cumulative oil production, thousand tons & 2536 & 4603 & 4609 & 4789 & 4833 \\
\hline 5. & Oil recovery factor & 0.09 & 0.155 & 0.156 & 0.162 & 0.163 \\
\hline \multirow[t]{5}{*}{6.} & Solution gas oil ratio & 14 & 20 & 22 & 24 & 26 \\
\hline & In which: production well & 13 & 16 & 18 & 20 & 22 \\
\hline & Injection well & - & 2 & 2 & 2 & 2 \\
\hline & Sidetrack & & 2 & 2 & 2 & 2 \\
\hline & In suspension & 1 & - & - & - & - \\
\hline 7. & Ratio between the injection well stock and production well stock & - & 0.125 & 0.111 & 0.1 & 0.091 \\
\hline 8. & Production drilling, thousand (m) & & 20,026 & 28,411 & 37,372 & 45,309 \\
\hline 9. & Average water cut at the end of development period (\%) & 32.9 & 62.2 & 67.1 & 65.1 & 65.0 \\
\hline 10 . & $\begin{array}{l}\text { Geological reserves for } 1 \text { well, thousand tons } \\
\text { Cumulative production rate for } 1 \text { well, thousand tons }\end{array}$ & $\begin{array}{l}2287 \\
181\end{array}$ & $\begin{array}{l}1486 \\
230\end{array}$ & $\begin{array}{l}1351 \\
210\end{array}$ & $\begin{array}{l}1234 \\
200\end{array}$ & $\begin{array}{l}1143 \\
186\end{array}$ \\
\hline
\end{tabular}


Table 4 Comparison of the predictive specific oil production of wells
Fig. 14 Comparison of dynamics of well stock change and oil production in the cases 2 and 5

\begin{tabular}{|c|c|c|c|c|c|}
\hline WHP & Well & Option 2 & Option 5 & $\Delta t$ ton. & Remark \\
\hline \multirow{13}{*}{$\mathrm{RC}-4$} & 20 & 231 & 121 & -111 & \\
\hline & 25 & 94 & 95 & 1 & \\
\hline & 420 & 64 & 64 & 0 & Injection \\
\hline & 421 & 7 & 7 & 0 & \\
\hline & 421_ST & 130 & 130 & 0 & Sidetrack \\
\hline & 422 & 371 & 179 & -191 & \\
\hline & 423 & 64 & 621 & -43 & \\
\hline & 424 & $\leq 4$ & 447 & -307 & \\
\hline & 425 & 80 & 42 & -39 & \\
\hline & 426 & 137 & 132 & -5 & \\
\hline & 427 & - & 161 & 161 & Option 3 \\
\hline & P1 & - & 350 & 350 & Option 4 \\
\hline & $\mathrm{P} 3$ & - & 163 & 163 & Option 5 \\
\hline \multirow{13}{*}{$\mathrm{RC}-\mathrm{DM}$} & $2 X$ & 362 & 317 & -45 & \\
\hline & $3 X$ & 293 & 198 & -95 & \\
\hline & 404 & - & - & - & \\
\hline & 404_ST & 156 & 156 & 0 & Sidetrack \\
\hline & 405 & 57 & 50 & -8 & \\
\hline & 406 & 41 & 41 & 0 & Injection \\
\hline & 407 & 143 & 516 & -127 & \\
\hline & 408 & 112 & 106 & -5 & \\
\hline & 409 & 251 & 218 & -33 & \\
\hline & 410 & 154 & 133 & -21 & \\
\hline & 411 & - & 173 & 173 & Option 3 \\
\hline & $\mathrm{P} 2$ & - & 249 & 249 & Option 4 \\
\hline & $\mathrm{P} 4$ & - & 160 & 160 & Option 5 \\
\hline \multicolumn{2}{|c|}{ total } & 4603 & 4833 & 230 & \\
\hline
\end{tabular}

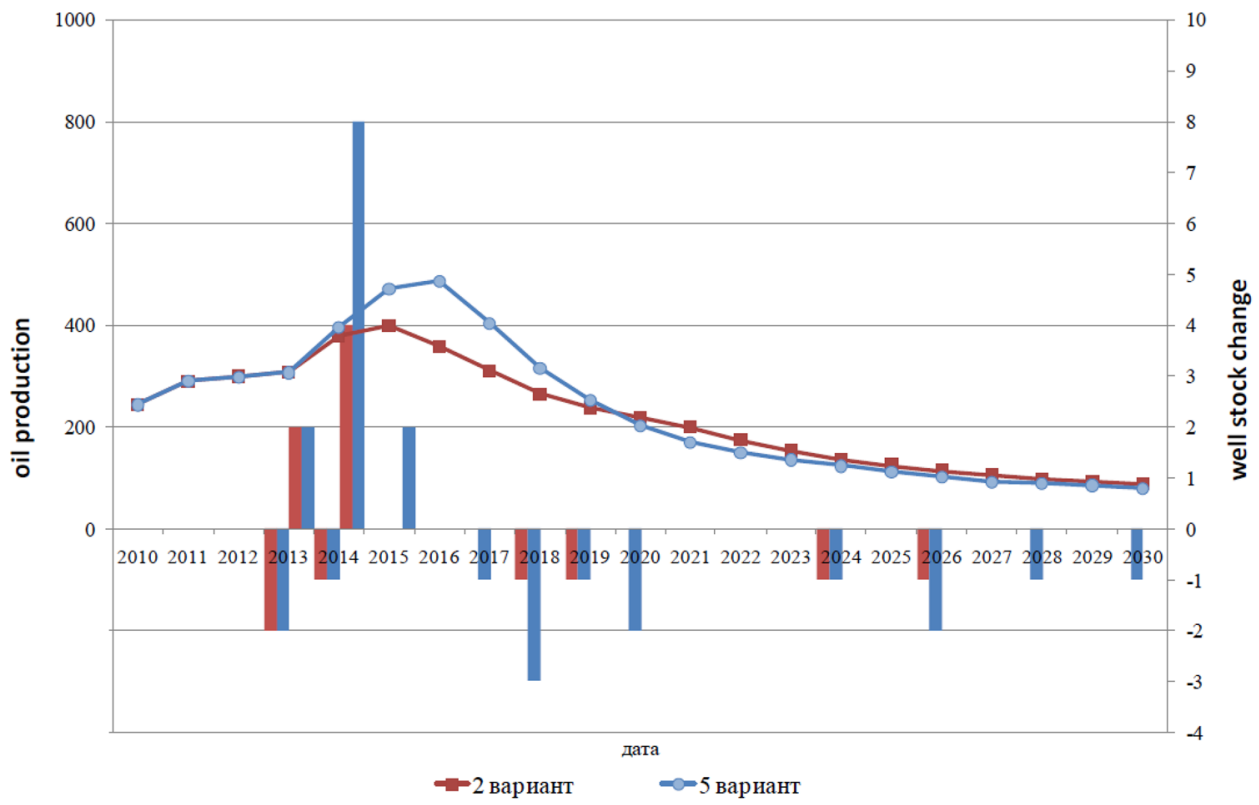




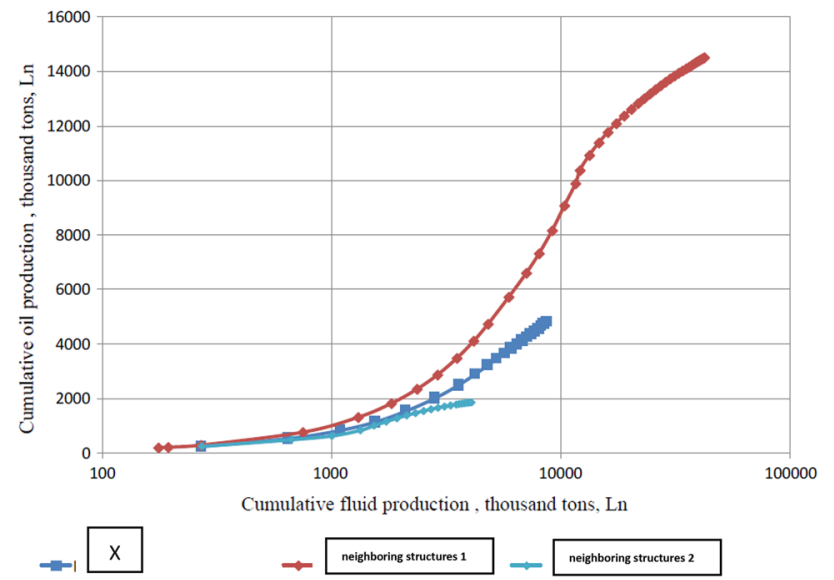

Fig. 15 Driving-out curves of blocks of neighboring structures field

The main way to improve the technology and systems of the field development is to increase the efficiency of the production process by increasing the displacement parameters of residual oil and reservoir sweep efficiency by stimulation.

\section{Summary and conclusions}

This study proposed the history matching process and field development plan to optimize oil production in crystalline basement reservoir. The key points drawn from this work include the following:

- The nearly perfect history matching model could be achieved by calibrating aquifer size and permeability distribution.

- The field development plan provides the better evaluation about technological parameters

- Water injection for reservoir pressure maintenance highly contributed to improve oil recovery in crystalline basement reservoir

- Increasing the well number is less effective than reservoir pressure maintenance in terms of oil recovery factor

- The option 5 is the optimal field development in crystalline basement reservoir of $\mathrm{X}$ field.

- Forecast results of production with recovery coefficients in the range of $10-13 \%$ are relatively suitable for neighboring fields.

Table 5 Comparison of the oil recovery factor depending on the well stock and production regime

\begin{tabular}{|c|c|c|c|c|}
\hline Production regime & Options & $\begin{array}{l}\text { Cumulative } \\
\text { oil production } \\
\left(1000 \mathrm{~m}^{3}\right)\end{array}$ & $\begin{array}{l}\text { Increment to } \\
\text { the base case } \\
\left(1000 \mathrm{~m}^{3}\right)\end{array}$ & $\begin{array}{l}\text { Oil } \\
\text { recovery } \\
\text { factor }\end{array}$ \\
\hline \multirow[t]{8}{*}{ Natural drive } & Base case (13 wells) & 2918 & 0.0 & 0.085 \\
\hline & Base case +2 new wells & 3371 & 453 & 0.098 \\
\hline & Base case +4 new wells & 3525 & 607 & 0.103 \\
\hline & Base case +4 new wells +2 sidetracks & 3616 & 698 & 0.105 \\
\hline & Base case +6 new wells. & 3555 & 637 & 0.104 \\
\hline & Base case +6 new wells +2 sidetracks & 3658 & 740 & 0.107 \\
\hline & Base case +10 new wells & 3605 & 687 & 0.106 \\
\hline & Base case +10 new wells +2 sidetracks & 3702 & 784 & 0.108 \\
\hline \multirow{4}{*}{$\begin{array}{l}\text { Natural drive with an artificial } \\
\text { system of reservoir pressure main- } \\
\text { tenance }\end{array}$} & $\begin{array}{l}\text { Base case }+4 \text { new wells }+2 \text { sidetracks }+ \text { water injec- } \\
\text { tion }(406 \text { and } 420)\end{array}$ & 5302 & 2384 & 0.155 \\
\hline & $\begin{array}{l}\text { Base case }+6 \text { new wells }+2 \text { sidetracks }+ \text { reservoir } \\
\text { pressure maintenance }(406 \text { and } 420)\end{array}$ & 5309 & 2391 & 0.156 \\
\hline & $\begin{array}{l}\text { Base case }+8 \text { new wells }+2 \text { sidetracks }+ \text { reservoir } \\
\text { pressure maintenance ( } 406 \text { and } 420)\end{array}$ & 5517 & 2599 & 0.162 \\
\hline & $\begin{array}{l}\text { Base case }+10 \text { new wells }+2 \text { sidetracks }+ \text { reservoir } \\
\text { pressure maintenance }(406 \text { and } 420)\end{array}$ & 5567 & 2649 & 0.163 \\
\hline
\end{tabular}


However, there are some limitations as follows:

$\mathrm{X}$ basement is type I fractured reservoir in Nelson classification which characterized as permeability and storage are in deformation structures, not the standard porous media. The reservoir may have extremely low porosity at very high permeability and extreme anisotropy of permeability. There will be no conventional relative permeability — saturation relationships that are dependent on flow velocity and direction. The extreme sensitivity of water cut to pressure and rate boundary conditions need to be considered during the history matching of the model.

The input data have not yet updated the actual MPLT (Memory Production Logging Tool) results into the model. Good match history results with local adjustments in wells are acceptable at this time, but it does not match GOR parameters, since the measured data are not reliable. Regarding the forecast for production, it is recommended to run more cases with the number of wells of 3,4 , and 5 wells to evaluate the base case selection as 6 wells.

Further research should consider the type of enhancement of oil recovery to maximize the oil production in tertiary stage.

Acknowledgements This research is funded by Ho Chi Minh City University of Technology-VNU-HCM under grant number T-ĐCDK-2018-06.

Open Access This article is distributed under the terms of the Creative Commons Attribution 4.0 International License (http://creativeco mmons.org/licenses/by/4.0/), which permits unrestricted use, distribution, and reproduction in any medium, provided you give appropriate credit to the original author(s) and the source, provide a link to the Creative Commons license, and indicate if changes were made.

\section{References}

Alfarge D, Wei M, Bai B (2018) Numerical simulation study on miscible EOR techniques for improving oil recovery in shale oil reservoirs. J Pet Explor Prod Technol 8:901-916. https://doi. org/10.1007/s13202-017-0382-7

Ashraf U, Zhu P, Yasin Q, Anees A, Imraz M, Mangi HN, Shakeel S (2019) Classification of reservoir facies using well log and 3D seismic attributes for prospect evaluation and field development: a case study of Sawan gas field, Pakistan. J Pet Sci Eng 175:338351. https://doi.org/10.1016/j.petrol.2018.12.060

Azim RA (2016) Integration of static and dynamic reservoir data to optimize the generation of subsurface fracture map. J Pet Explor Prod Technol 6:691-703. https://doi.org/10.1007/s1320 2-015-0220-8

Babadagli T (2007) Development of mature oil fields-A review. J Pet Sci Eng 57:221-246. https://doi.org/10.1016/j.petrol.2006.10.006

Blaskovich FT (2000) Historical problems with old field rejuvenation. In: Asia Pacific conference on integrated modelling for asset management, Yokohama, Japan, 25-26 April 2000. https://doi. org/10.1306/a96734aa-1738-11d7-8645000102c1865d

Dachanuwattana S, Yu W, Sepehrnoori K (2019) An efficient MCMC history matching workflow using fit-for-purpose proxies applied in unconventional oil reservoirs. J Pet Sci Eng 176:381-395. https ://doi.org/10.1016/j.petrol.2019.01.070

Dakhelpour-Ghoveifel J, Shegeftfard M, Dejam M (2018) Capillarybased method for rock typing in transition zone of carbonate reservoirs. J Pet Explor Prod Technol. https://doi.org/10.1007/s1320 2-018-0593-6

Dang CTQ, Chen Z, Nguyen NTB, Bae W, Phung TH, Dong CC (2011) A successful story of integration geological characterization, reservoir simulation, assisted history matching and EOR in a giant fractured granite basement: a road map to maximize recovery in unconventional reservoirs. In: Offshore technology conference, Houston, Texas, USA, 2-5 May 2011, pp 1-12. https://doi. org/10.4043/21454-ms

Dejam M, Hassanzadeh H, Chen Z (2018) Semi-analytical solution for pressure transient analysis of a hydraulically fractured vertical well in a bounded dual-porosity reservoir. J Hydrol 565:289-301. https://doi.org/10.1016/j.jhydrol.2018.08.020

Giao PH, Trung BD, Minh NH (2011) Reservoir in fractured granite basement (Fgb): unconventional or conventional? In: International petroleum technology conference, Thailand, 15-17 November. https://doi.org/10.2523/iptc-15465-abstract

Gutmanis J (2009) Basement reservoirs-A review of their geological and production characteristics. In: International petroleum technology conference, Doha, Qatar, 7-9 December, pp 1-7. https:// doi.org/10.2523/iptc-13156-ms

He L, Mei H, Hu X, Dejam M, Kou Z, Zhang M (2019) Advanced flowing material balance to determine original gas in place of shale gas considering adsorption hysteresis. SPE Reserv Eval Eng. https:// doi.org/10.2118/195581-PA

Isebor OJ, Durlofsky LJ (2014) Biobjective optimization for general oil field development. J Pet Sci Eng 119:123-138. https://doi. org/10.1016/j.petrol.2014.04.021

Izadmehr M, Daryasafar A, Bakhshi P, Tavakoli R, Ghayyem MA (2018) Determining influence of different factors on production optimization by developing production scenarios. J Pet Explor Prod Technol 8:505-520. https://doi.org/10.1007/s1320 2-017-0351-1

Jeong D, Jeong K, Baik H (2013) Uncertainty analyses of basement fracture reservoir performances using proxy models with highquality history matching. Energy Explor Exploit 31:395-409. https://doi.org/10.1260/0144-5987.31.3.395

Khan RA, Awotunde AA (2018) Determination of vertical/horizontal well type from generalized field development optimization. J Pet Sci Eng 162:652-665. https://doi.org/10.1016/j.petro 1.2017.10.083

León Carrera MF, Barbier M, Le Ravalec M (2018) Accounting for diagenesis overprint in carbonate reservoirs using parametrization technique and optimization workflow for production data matching. J Pet Explor Prod Technol 8:983-997. https://doi. org/10.1007/s13202-018-0446-3

Mashayekhizadeh V, Dejam M, Ghazanfari MH (2011) The application of numerical Laplace inversion methods for type curve development in well testing: a comparative study. Pet Sci Technol 29:695707. https://doi.org/10.1080/10916460903394060

Nguyen NT, Dang CTQ, Bae W (2011) Geological characteristics and integrated development plan for giant naturally fractured basement reservoirs. Can Unconv Resour Conf. https://doi. org/10.2118/149510-MS

Qiu X, Tan SP, Dejam M, Adidharma H (2019) Simple and accurate isochoric differential scanning calorimetry measurements: phase transitions for pure fluids and mixtures in nanopores. Phys Chem Chem Phys 21:224-231. https://doi.org/10.1039/c8cp06691d

Saboorian-Jooybari H, Dejam M, Chen ZJ, Pourafshary P (2015) Fracture identification and comprehensive evaluation of the parameters by dual laterolog data. In: SPE middle east unconventional

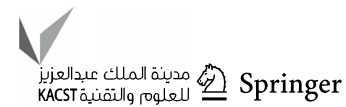


resources conference and exhibition, Muscat, Oman, 26-28 January 2015, pp 1-11. https://doi.org/10.2118/172947-ms

Saboorian-Jooybari H, Dejam M, Chen Z, Pourafshary P (2016) Comprehensive evaluation of fracture parameters by dual laterolog data. J Appl Geophys 131:214-221. https://doi.org/10.1016/j. jappgeo.2016.06.005

Santos SMG, Gaspar ATFS, Schiozer DJ (2017) Risk management in petroleum development projects: technical and economic indicators to define a robust production strategy. J Pet Sci Eng 151:116127. https://doi.org/10.1016/j.petrol.2017.01.035

Tan SP, Qiu X, Dejam M, Adidharma H (2019) Critical point of fluid confined in nanopores: experimental detection and measurement. J Phys Chem C 123:9824-9830. https://doi.org/10.1021/ acs.jpcc.9b00299

Wilson KC, Durlofsky LJ (2013) Optimization of shale gas field development using direct search techniques and reduced-physics models. J Pet Sci Eng 108:304-315. https://doi.org/10.1016/j. petrol.2013.04.019

Yang H, Kim J, Choe J (2017) Field development optimization in mature oil reservoirs using a hybrid algorithm. J Pet Sci Eng 156:41-50. https://doi.org/10.1016/j.petrol.2017.05.009

Zhang L, Kou Z, Wang H, Zhao Y, Dejam M, Guo J, Du J (2018) Performance analysis for a model of a multi-wing hydraulically fractured vertical well in a coalbed methane gas reservoir. J Pet Sci Eng 166:104-120. https://doi.org/10.1016/j.petrol.2018.03.038

Publisher's Note Springer Nature remains neutral with regard to jurisdictional claims in published maps and institutional affiliations. 